\title{
Anterior Pituitary Gland Neoplasm
}

National Cancer Institute

\section{Source}

National Cancer Institute. Anterior Pituitary Gland Neoplasm. NCI Thesaurus. Code C45921.

A neoplasm arising from the anterior lobe of the pituitary gland. The vast majority are adenomas. 